\title{
PENGANTAR TERAPI KOMPLEMENTER DAN KEPERAWATAN HOLISTIK
}

Anung Ahadi Pradana

STIKes Mitra Keluarga, Bekasi-Jawa Barat, anung.ahadi@stikesmitrakeluarga.ac.id

\section{Konsep Keperawatan Holistik}

Pelayanan kesehatan terus mengalami perubahan sejalan dengan kemajuan ilmu pengetahuan dan teknologi kesehatan. Selain itu, kompleksitas permasalahan kesehatan yang dihadapi masyarakat juga menuntut adanya respon yang efektif dari pelayanan kesehatan dan tenaga kesehatan. Kapasitas profesional perawatan kesehatan untuk mengantisipasi kebutuhan masyarakat akan kualitas layanan perawatan kesehatan, dan memenuhi kebutuhan dengan intervensi yang terbukti secara ilmiah adalah kunci keberhasilan dan kualitas layanan perawatan kesehatan yang efektif. Dampak teknologi canggih dalam perawatan kritis juga telah menarik konsentrasi perawat pada prosedur teknis penggunaan mesin canggih daripada memberikan perawatan holistik yang komprehensif bagi pasien (Ibrahim, 2011).

Konsep Florence Nightingale tentang keperawatan merupakan landasan utama perawat modern dalam memberikan asuhan keperawatan melalui integrasi antara lingkungan dan manusia. Dalam perawatan pasien, penilaian subyektif perawat terhadap kondisi pasien sering kali diabaikan demi obyektifitas pengukuran yang telah ditentukan melalui standar rumah sakit. Dalam memberikan asuhan keperawatan, seorang perawat harus menggunakan segala pengetahuan yang dimiliki sebagai dasar ilmiah dalam melakukan tindakan keperawatan dengan berfokus pada kesejahteraan pasien. Dengan mengembangkan rasa hormat kepada pasien sebagai makhluk yang unik dapat membantu perawat dalam mengintegrasikan pesan florence nightingale terkait hubungan lingkungan-individu dalam konteks sehat sakit (Karoliussen \& Hov, 2020). 


\section{Gambar 1.1. Hierarki Maslow Sebagai Landasan Keperawatan Holistik}

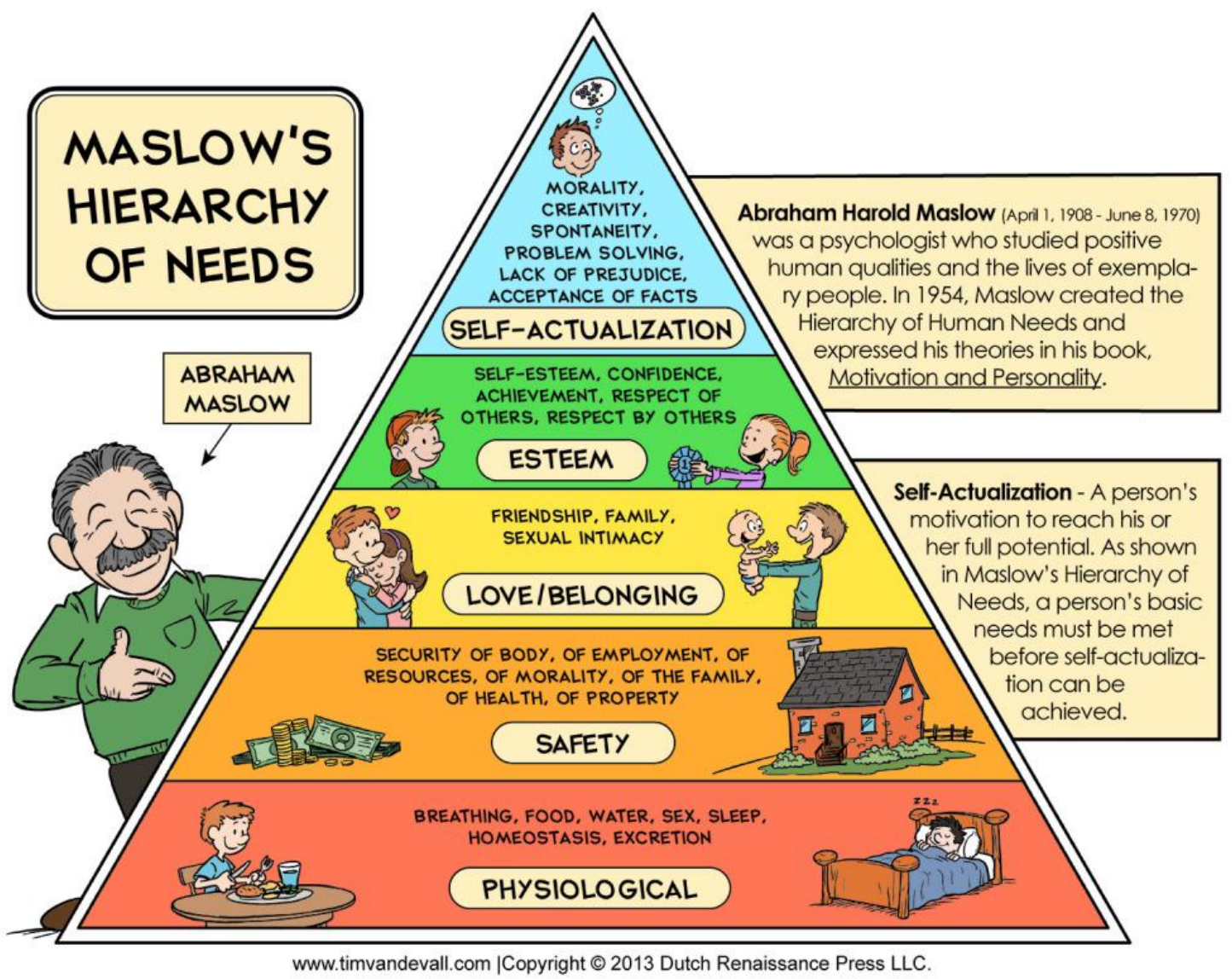

Sumber: https://images.app.goo.gl/xS33GrvrVut17H9MA

Prinsip holistik diketahui telah menjadi landasan praktik keperawatan dengan menggabungkan pengobatan alami dan terapi modern sejak tahun 1700-an. Penggunaan kompres, plester, minyak, obat gosok, salep, dan teh yang terbuat dari ramuan obat merupakan praktik umum pada saat itu hingga periode 1900-an. Kurikulum dan praktik keperawatan holistik membahas aspek fisiologis, psikologis, sosiologis, emosional, relasional, dan spiritual manusia secara utuh dan saling terkait satu sama lain. Sementara prinsip-prinsip holistik dan terapi alami merupakan dasar dalam praktik awal keperawatan, prinsip-prinsip tersebut sebagian besar ditinggalkan pada pertengahan hingga akhir tahun 1900-an. Di bagian akhir tahun 1900-an, teknologi menggantikan hubungan pasien dan pelayanan kesehatan yang mulai berubah dari "profesi jasa" menjadi "bisnis yang mencari keuntungan". Hubungan kepedulian dan penyembuhan yang fundamental untuk mencapai kesembuhan pasien melalui proses keperawatan dikalahkan oleh budaya efisiensi dan 
menghargai margin keuntungan yang muncul, akibatnya perawat dibuat frustrasi oleh ketidakmampuan mereka untuk memberikan perawatan yang berkualitas dan untuk memenuhi kebutuhan individu secara keseluruhan (Thornton, 2019).

Lingkungan penyembuhan yang optimal/optimal healing environment (OHE) didefinisikan sebagai komponen sosial, psikologis, spiritual, fisik, dan perilaku dari perawatan kesehatan yang mendukung penyembuhan dalam pencapaian kesejahteraan pasien. Integrasi dan asimilasi prinsip OHE termasuk menyeimbangkan keadaan finansial pasien, kepemimpinan yang berpusat pada pasien, keterlibatan komunitas, dan hubungan pikiran-tubuh dalam konsep asuhan perawatan yang terintegrasi. Sistem pemberian asuhan keperawatan saat ini mulai menuju kondisi yang lebih efisien dan efektif, serta peka terhadap kebutuhan dan preferensi konsumen. Beberapa rumah sakit berupaya memperbaiki lingkungan yang mendukung proses penyembuhan pasien yang dilayaninya (Lincoln \& Johnson, 2009)

Mengingat pentingnya peningkatan kesadaran perawat untuk berpikir dan mengintegrasikan nilai-nilai keperawatan holistik ke dalam praktik keperawatan, maka diperlukan upaya yang signifikan untuk menggali, memahami serta mengimplementasikan nilai-nilai keperawatan holistik. Evaluasi dan refleksi berkelanjutan tentang praktik keperawatan diperlukan untuk memeriksa apakah perawatan pasien telah memenuhi standar perawatan yang komprehensif, holistik, dan kualitas. Hal tersebut tentu akan menghasilkan tidak hanya penyembuhan penyakit tetapi juga penyembuhan dan kepuasan pasien dan keluarga terhadap layanan perawatan kesehatan (Ibrahim, 2011). Keperawatan Holistik dapat dikatakan sebagai suatu jenis praktik keperawatan yang berfokus pada pengobatan pasien secara menyeluruh yang tidak hanya mengobati gejala yang muncul (RegisteredNurses.Org, 2021).

Keperawatan holistik adalah pelayanan professional yang didasarkan ilmu dan keperawatan alternatif dan atau komplementer berbentuk pelayanan biologis, psikologis, kognisi, social, kultural dan spiritual yang saling mempengaruhi baik sehat dan sakit yang mencakup seluruh siklus kehidupan manusia. 


\section{Gambar 1.2. Skema Keperawatan Holistik}

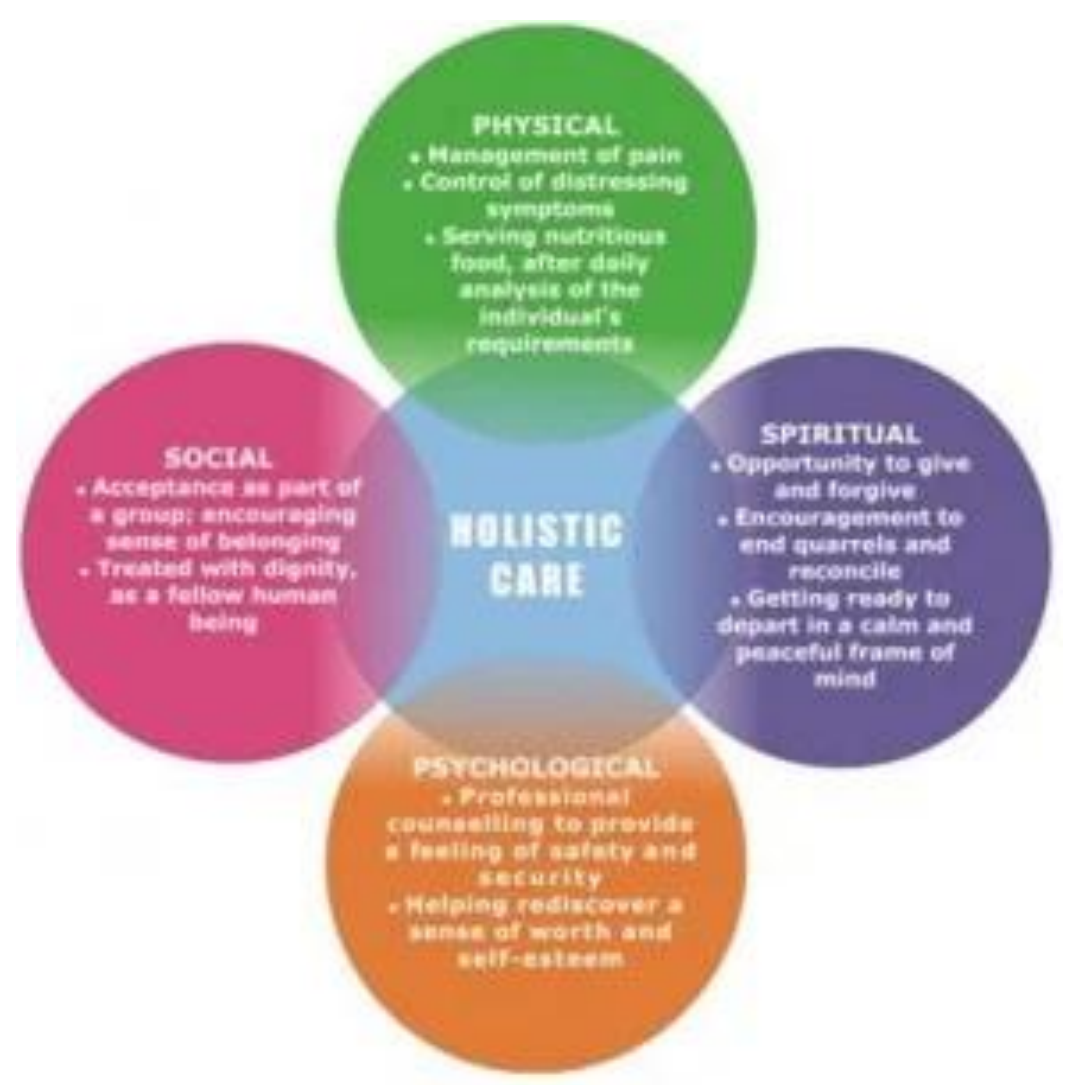

Sumber: https://images.app.goo.gl/9Pdxe3x2zKszG4yq6

Teori Keperawatan yang melandasi Keperawatan Holistik:

1. Teori keperawatan dari Florence Nightingale

2. Jean Watson (The Theory of Human Caring)

3. Martha Rogers (The Science of Unitary Human Beings)

4. Margaret Newman (Health as Expanding Consciousness )

5. Madeline Leininger (Theory of Cultural Care)

6. Rosemarie Rizzo Parse (Theory of Human Becoming)

7. Paterson and Zderad (Humanistic Nursing Theory)

8. Helen Erickson (Modeling and Role Modeling)

\section{Jenis Keperawatan Holistik}

National Center for Complementary/Alternative Medicine (NCCAM) membuat klasifikasi dari berbagai terapi dan sistem pelayanan dalam lima kategori. 
1. Mind-body therapy yaitu memberikan intervensi dengan berbagai teknik untuk memfasilitasi kapasitas berpikir yang mempengaruhi gejala fisik dan fungsi tubuh misalnya perumpamaan ( imagery), yoga, terapi musik, berdoa, journaling, biofeedback , humor, tai chi, dan terapi seni.

2. Sistem pelayanan alternatif yaitu sistem pelayanan kesehatan yang mengembangkan pendekatan pelayanan biomedis berbeda dari Barat misalnya pengobatan tradisional Cina, Ayurvedia, pengobatan asli Amerika, cundarismo, homeopathy, naturopathy.

3. Terapi biologis yaitu natural dan praktik biologis dan hasil-hasilnya misalnya herbal, makanan.

4. Terapi manipulatif dan sistem tubuh. Terapi ini didasari oleh manipulasi dan pergerakan tubuh misalnya pengobatan kiropraksi, macam-macam pijat, rolfing, terapi cahaya dan warna, serta hidroterapi.

5. Terapi energi yaitu terapi yang fokusnya berasal dari energi dalam tubuh (biofields) atau mendatangkan energi dari luar tubuh misalnya terapetik sentuhan, pengobatan sentuhan, reiki, external qi gong, magnet. berupa kombinasi antara biofield dan bioelektromagnetik.

\section{Perbedaan antara pendekatan terapi komplementer, alternatif dan integratif.}

Di seluruh dunia, sekitar 65 hingga 80 persen populasi dunia menggunakan terapi modalitas yang dikembangkan di luar pengobatan konvensional. Di Amerika Serikat, terapi modalitas dan penyembuhan non-konvensional biasa disebut dengan 3 istilah, antara lain: "komplementer", "alternatif", dan "integratif". Pendekatan komplementer, alternatif dan integratif bersifat holistik hanya sejauh digunakan untuk mendukung kesembuhan seseorang secara keseluruhan. Misalnya, herbal dapat digunakan secara holistik jika digunakan untuk mendukung penyembuhan seseorang, atau dapat digunakan secara allopatik jika hanya digunakan untuk mendukung tubuh fisik (American Holistic Nurses Association, 2021).

The National Institute of Health's National Center for Complementary and Integrative Health (NCCIH) yang terletak di Amerika Serikat adalah badan utama pemerintah federal Amerika Serikat untuk penelitian ilmiah tentang pendekatan komplementer, alternatif, dan integratif untuk kesehatan dan penyembuhan. Menurut NCCIH, lebih dari 30 persen orang dewasa dan sekitar 12 persen anak-anak di AS menggunakan terapi modalitas dan penyembuhan non-konvensional dalam mejaga kondisi kesehatannya. Orang-orang di AS sering menggunakan kata "alternatif" dan "komplementer" secara bergantian saat 
menjelaskan terapi penyembuhan non-konvensional. Sebagaimana yang diketahui terdapat nomenklatur berbeda antara terapi komplementer dengan terapi alternatif, perbedaan tersebut antara lain: (American Holistic Nurses Association, 2021)

1. Sebuah terapi dikatakan sebagai terapi komplementer apabila dipergunakan bersama dengan terapi medis konvensional lain.

2. Sebuah terapi dikatakan sebagai terapi alternatif apabila dipergunakan sebagai pengganti terapi medis konvensional lain.

3. Sebuah terapi dikatakan sebagai terapi integratif apabila dalam penggunaannya melibatkan penggabungan beberapa terapi konvensional secara terkoordinasi.

\section{Konsep Keperawatan Komplementer}

Keperawatan Komplementer adalah suatu bentuk terapi komplementer yang menggunakan teknik modalitas dan terapi tradisional yang dipergunakan bersamaan dengan terapi medis modern. Penamaan terapi komplementer dengan terapi holistik di beberapa negara sering kali dianggap sebagai hal yang sama. Kebutuhan akan layanan kesehatan komplementer menjadi bagian penting dalam pelayanan kesehatan di negara maju dan negara berkembang. Salah satu alasannya adalah filosofi holistik pada terapi komplementer, yaitu adanya harmoni dalam diri dan promosi kesehatan dalam terapi holistik. Alasan lainnya karena klien ingin terlibat untuk pengambilan keputusan dalam pengobatan dan peningkatan kualitas hidup dibandingkan sebelumnya.

Terapi komplementer yang ada menjadi salah satu pilihan pengobatan masyarakat. Pemilihan layanan ini membuka wawasan masyarakat tentang apa dan bagaimana layanan kesehatan holistik baik melalui media cetak maupun media internet. Masyarakat ingin mendapatkan pelayanan yang sesuai dengan pilihannya, sehingga apabila keinginan terpenuhi akan berdampak ada kepuasan klien (Himpunan Perawat Holistik Indonesia, 2018).

Tujuan utama dari teknik integrasi komplementer dalam keperawatan antara lain melakukan asuhan keperawatan melalui pendekatan whole-person dan whole-system dalam mencapai kondisi sejahtera pada diri individu. Individu sebagai bagian dari sistem dianggap sebagai bagian yang tidak terpisahkan dari lingkungan sekitarnya dan memiliki hubungan timbal balik dengan lingkungan yang dapat mempengaruhi kondisi kesehatan. Kondisi sejahtera pada diri individu muncul dari pendekatan asuhan keperawatan yang dilakukan pada 
beberapa determinan yang meliputi kondisi fisiologis, kebutuhan aman-nyaman, kebutuhan akan cinta dan mencintai, hingga aktualisasi diri (Rosa, 2017).

Sejumlah $82 \%$ klien melaporkan adanya reaksi efek samping dari pengobatan onvensional yang diterima menyebabkan memilih terapi komplementer. Alasan lainnya karena klien ingin terlibat untuk pengambilan keputusan dalam pengobatan dan peningkatan kualitas hidup dibandingkan sebelumnya. Bentuk terapi yang digunakan dalam terapi komplementer ini beragam sehingga disebut juga dengan terapi holistik. Terminologi kesehatan holistik mengacu pada integrasi secara menyeluruh dan mempengaruhi kesehatan, perilaku positif, memiliki tujuan hidup, dan pengembangan spiritual . Terapi komplementer dapat diterapkan dalam berbagai level pencegahan penyakit berupa promosi kesehatan, pencegahan penyakit ataupun rehabilitasi (Himpunan Perawat Holistik Indonesia, 2018).

Hasil penelitian pada 3 titik waktu (2002, 2007, dan 2012) pada masyarakat Amerika Serikat menunjukkan bahwa suplemen makanan non-vitamin dan non-mineral tetap menjadi terapi komplementer yang paling populer dipergunakan. Sementara penggunaan yoga, tai chi, dan qi gong meningkat secara linier di tiga titik waktu tersebut. Meskipun terdapat konsistensi dalam jenis pendekatan yang paling populer, terdapat variasi dalam tren di seluruh titik waktu (Clarke, Black, Stussman, Barnes, \& Nahin, 2015a). Adapun penjabaran hasil tersebut adalah sebagai berikut:

1. Suplemen makanan non-vitamin dan nonmineral adalah pendekatan terapi komplementer yang paling umum digunakan pada masing-masing dari tiga titik waktu: 18,9\% pada tahun 2002 dan tidak berubah dari 2007 hingga 2012 (17,7\%).

2. Latihan pernapasan dalam merupakan pendekatan terapi komplementer kedua yang paling umum digunakan pada tahun 2002 (11,6\%), 2007 (12,7\%), dan 2012 (10,9\%). Penggunaan yoga, tai chi, dan qi gong meningkat secara linier selama tiga titik waktu, dimulai dari 5,8\% pada tahun 2002, 6,7\% pada tahun 2007, dan 10,1\% pada tahun 2012 . Yoga adalah yang paling umum digunakan dari ketiga pendekatan ini di ketiga titik waktu.

3. Ada peningkatan linier kecil tapi signifikan dalam penggunaan pengobatan homeopati, akupunktur, dan naturopati. Penggunaan perawatan chiropraktik atau manipulasi kiropraktik dan osteopati adalah pendekatan keempat yang paling umum digunakan pada tahun 2002 (7,5\%), $2007(8,6 \%)$, dan $2012(8,4 \%)$. 
4. Meditasi digunakan oleh $7,6 \%$ orang dewasa pada tahun $2002,9,4 \%$ pada tahun 2007 , dan $8,0 \%$ pada tahun 2012, menjadikannya sebagai salah satu dari lima pendekatan teratas yang paling umum digunakan untuk setiap titik waktu.

5. Ayurveda, biofeedback, hipnosis citra terpandu, dan terapi penyembuhan energi memiliki prevalensi rendah secara konsisten dan tidak memiliki perubahan signifikan di tiga titik waktu.

\section{Diagram 1.1. 10 Terapi komplementer umum yang dipergunakan orang Dewasa di} Amerika Serikat periode 2012

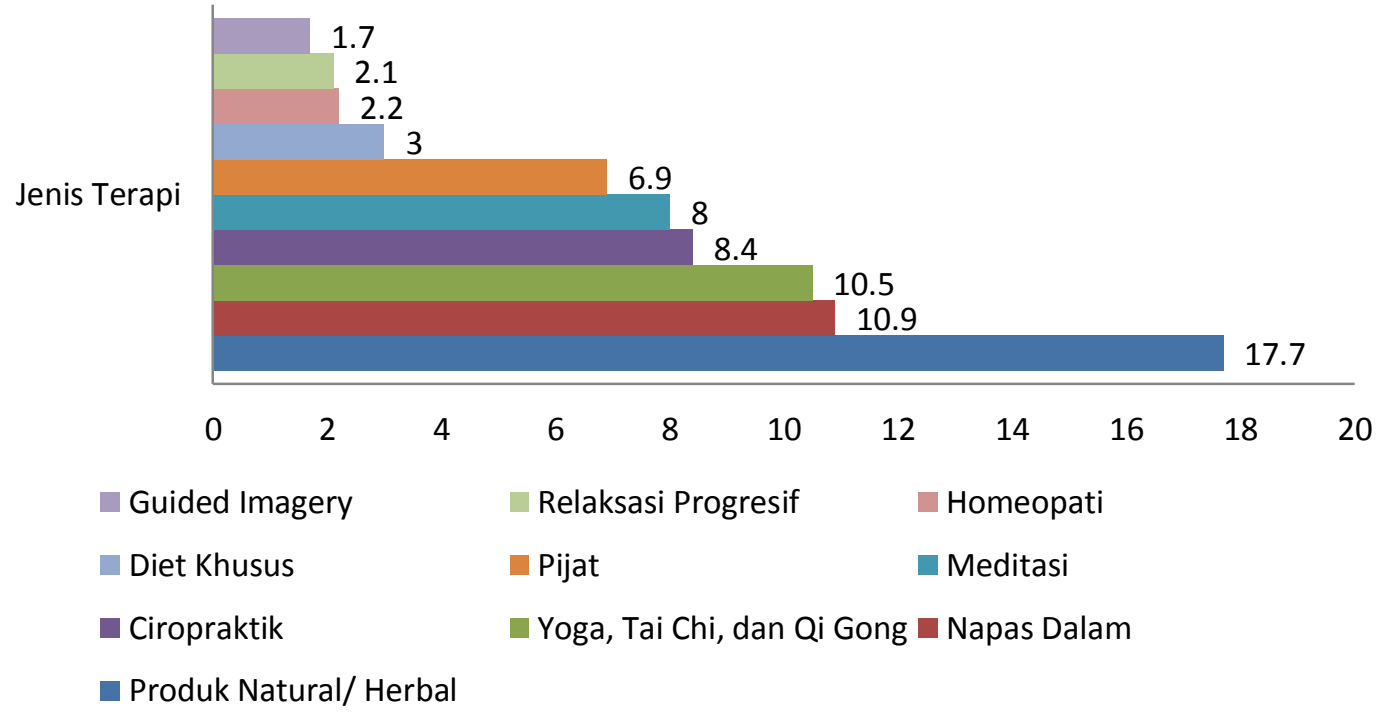

Sumber: Clarke, Black, Stussman, Barnes, \& Nahin (2015a)

Diagram 1.2. Persentase penggunaan terapi komplementer di Indonesia periode 2012

\section{Persentase}

- Tidak Memanfaatkan Pelayanan Kesehatan Tradisional

- Memanfaatkan Pelayanan Kesehatan Tradisional

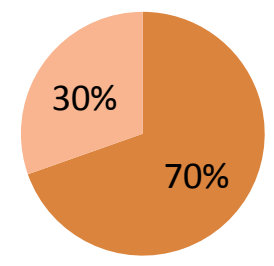

Sumber: (Kementrian Kesehatan Republik Indonesia, 2013) 


\section{Diagram 1.3. Terapi komplementer umum yang dipergunakan orang Dewasa di Indonesia periode 2012}

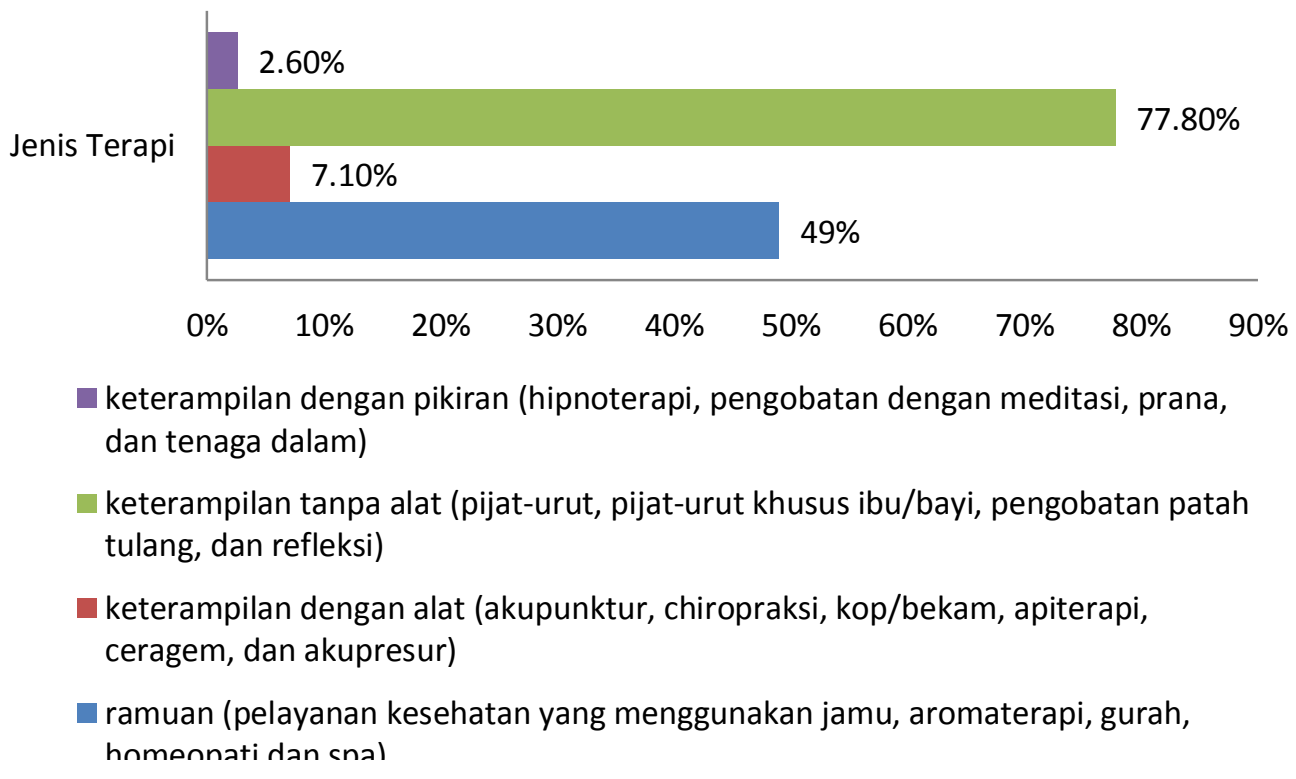

Sumber: (Kementrian Kesehatan Republik Indonesia, 2013)

Beberapa teknik dan terapi umum yang digunakan oleh perawat holistik:

1. Akupunktur

2. Bantu pasien dalam teknik manajemen stres

3. Aromaterapi

4. Pijat

5. Hipnosis, hidroterapi, dan balneoterapi

6. Praktik penyembuhan Tiongkok dan Timur

7. Pembinaan kesehatan

Perawat komplementer menggunakan kombinasi pengobatan Timur dan Barat untuk merawat pasien dan mengajari komunitas mereka tentang kesehatan dan perawatan kesehatan bersifat preventif. Bagi seorang perawat komplementer, kesehatan manusia memerlukan lebih dari sekedar kesejahteraan fisiknya., Kesehatan sejati dalam diri seseorang tidak hanya mencakup kesehatan fisik, tetapi juga kesehatan psikologis, emosional, spiritual, dan sosial. 


\section{Gambar1.3 Pendekatan Holistik Perawat Komplementer}

\section{Holistic Approach}

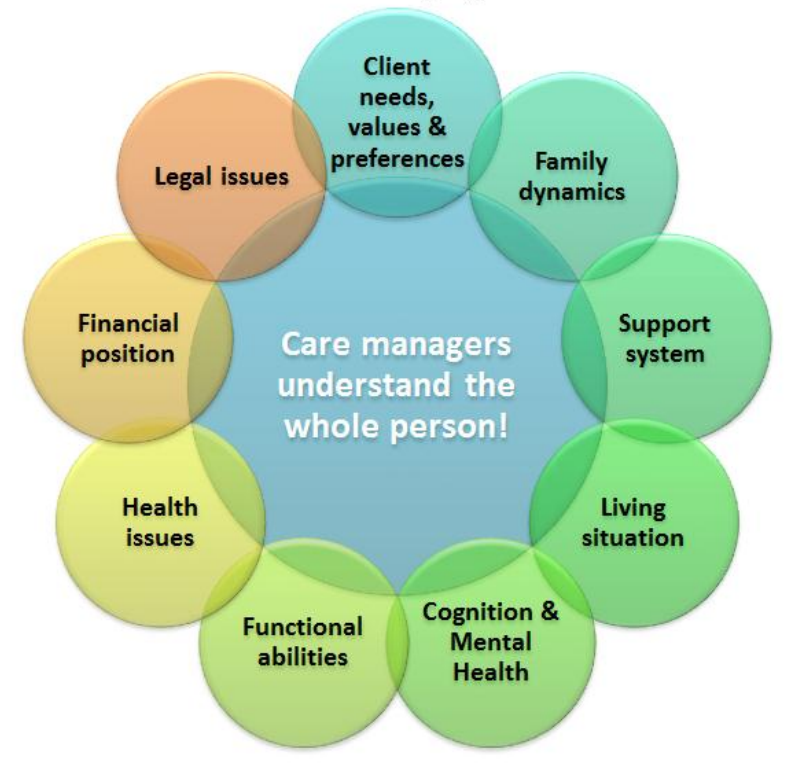

Sumber: https://images.app.goo.gl/GD4si6TRzFJ1R7eM6

\section{Etik Legal Terapi Komplementer}

Perawat memiliki kewajiban dalam memenuhi hak pasien dalam memperoleh pelayanan kesehatan optimal sebagaimana terdapat dalam UU Kesehatan no 23 tahun 1992 pasal 14. Dalam menjalankan kewajibannya, perawat mempunyai wewenang melakukan praktik keperawatan holistik baik secara mandiri maupun terintegrasi dengan layanan kesehatan di rumah sakit (UU no 38 tahun 2014.). Tantangan keperawatan kedepan adalah mengintegrasikan keperawatan holistik ke dalam sistem kesehatan nasional, meningkatkan kuantitas dan kualitas ilmu pengetahuan dan ketrampilan keperawatan holistik yang didukung hasil penelitian. Di negara maju, layanan holistik telah terintegrasikan dengan sistem kesehatan nasional bahkan pendidikan kesehatan, hal inipun di dukung hasil penelitian yang semakin marak tentang keperawatan komplementer.

Perawat holistik harus memiliki gelar pendidikan tinggi keperawatan. Di luar negeri, setelah mendapatkan BSN atau ADN, perawat selanjutnya memenuhi syarat untuk mengikuti ujian NCLEX-RN negara bagian mereka. Perawat holistik, seperti RN, harus lulus Ujian Lisensi Dewan Nasional (NCLEX-RN) sebelum diizinkan bekerja. Setelah lulus NCLEX-RN, RN dapat mengajukan permohonan sertifikasi dalam keperawatan holistik melalui American 
Holistic Nurses Certification Corporation. Agar memenuhi syarat untuk sertifikasi, RN harus menunjukkan bukti melanjutkan pendidikan dalam keperawatan holistik dan harus menyelesaikan serta lulus penilaian kualitatif dan ujian kuantitatif untuk mendapatkan sertifikasi.

Keperawatan holistik diakui oleh American Nurses Association (ANA) sebagai spesialisasi keperawatan dengan cakupan dan standar praktik yang ditentukan di mana semua perawat holistik bertanggung jawab. Keperawatan holistik didasarkan pada:

1. Sebuah badan pengetahuan yang unik

2. Penelitian berbasis bukti (EBN)

3. Keterampilan yang profesional

4. Standar praktik yang terstandarisasi

5. Keragaman bentuk terapi modalitas dari berbagai praktik kesehatan

6. Filsafat hidup dan keberadaan yang didasarkan pada kepedulian, hubungan, dan keterkaitan

\section{Asosiasi Perawat Holistik:}

1. American Holistic Nurses Association (AHNA)

2. American Holistic Nurses Credentialing Corp. (AHNCC)

3. Canadian Holistic Nurses Association (CHNA)

4. Himpunan Perawat Holistik Indonesia (HPHI)

\section{Peraturan terkait:}

1. Undang-Undang Nomor 36 Tahun 2009 tentang Kesehatan

2. Undang-Undang Nomor 44 Tahun 2009 tentang Rumah Sakit

3. Undang-Undang Nomor 36 Tahun 2014 tentang Tenaga KesehatanPeraturan Pemerintah Nomor 103 Tahun 2014 tentang Pelayanan Kesehatan Tradisional

4. Keputusan Menteri Kesehatan Nomor 381/Menkes/SK/III/2007 tentang Kebijakan Obat Tradisional

5. Keputusan Menteri Kesehatan Nomor 261/Menkes/SK/IV/2009 tentang Farmakope Herbal 


\section{Peran Perawat dalam Terapi Komplementer}

Ketika masyarakat barat menjadi lebih beragam semenjak globalisasi, ada kebutuhan yang semakin besar bagi perawat dan sistem kesehatan secara lebih umum untuk mengembangkan kebijakan dan praktik yang mempromosikan kompetensi budaya dan mendorong pemberian perawatan kesehatan holistik. Hal ini dapat memberikan dampak perubahan pada konsep pendidikan perawat, serta cara perawatan kesehatan yang diberikan serta jenis penelitian yang akan dilakukan terkait keperawatan ke depannya (Maddalena, 2009)

Selama beberapa tahun terakhir, pendidikan keperawatan holistik menjadi lebih umum ditemukan pada dunia keperawatan di negara maju jika dibandingkan negara-negara berkembang, hal ini merupakan hasil dari keinginan serta inisiatif tinggi dari organisasi profesi serta pihak pemerintah yang secara terus menerus mendorong perkembangan praktik keperawatan holistik. Sementara praktik keperawatan holistik di negara berkembang mengalami hambatan akibat terbatasnya sumber daya, aksesibilitas perawat terhadap pelatihan dan sertifikasi teknik komplementer yang relatif rendah dan sulit untuk diakses. Ilmu keperawatan holistik dianggap perlu untuk direncanakan serta dikembangkan sebagai suatu model pendidikan keperawatan berbasis prinsip holistik melalui pendekatan peka budaya yang melibatkan ilmu keperawatan lain (Rosa, 2017).

Kenyamanan holistik adalah konsep berbasis bukti (evidence based). Mengajar mahasiswa keperawatan dari perspektif holistik dapat memberikan efek secara positif tidak hanya pada pengalaman siswa tetapi juga pada efikasi diri pengajar. Penelitian terbaru menunjukkan bahwa tingkat efikasi diri pengajar di fakultas keperawatan berada pada tingkat sedang (moderate) dalam kaitannya dengan penerapan praktik berbasis bukti dalam pengajaran. Florence Nightingale, peletak gagasan awal keperawatan modern menjelaskan bahwa pendidikan keperawatan yang berfokus pada prinsip holistik adalah bagian integral dalam asuhan keperawatan (Gazza \& Hunker, 2014).

\section{Faktor efektif dalam menyediakan pelayanan holistik Meliputi:}

\section{Struktur pendidikan}

Struktur pendidikan mencakup konten program pendidikan, metode pengajaran, dan kompetensi pendidik memiliki dampak penting pada penerapan asuhan holistik oleh perawat. 


\section{Lingkungan profesional}

Lingkungan profesional, yang terdiri dari beban kerja, manajemen, dan terbatasnya kesesuaian lingkungan klinis dengan norma profesional, dapat menjadi pengaruh.

\section{Faktor motivasi}

Faktor pengalaman, karakter, dan nilai yang dianut dapat mendorong perawat untuk memperhatikan beragam kebutuhan pasien dan menyediakan perawatan holistik.

Keperawatan holistik diakui sebagai spesialisasi oleh Asosiasi Perawat Amerika pada tahun 2006, dan telah memiliki berbagai tolak ukur utama, visi-misi, tujuan nasional serta standar praktik keperawatan holistik yang menjadi pedoman dalam praktik anggotanya (American Holistic Nurses Association, 2016). Di Indonesia sendiri, Himpunan Perawat Holistik Indonesia berdiri pada tahun 2015 yang bertujuan untuk: (Himpunan Perawat Holistik Indonesia, 2015)

1. Menghimpun dan menyatukan seluruh Ners - perawat Indonesia yang bekerja dan mengabdikan diri dalam bidang keperawatan berbasis holistik di Indonesia.

2. Mengembangkan ilmu pengetahuan dan teknologi keperawatan holistik dengan cara Memadukan segenap potensi perawat holistiK Indonesia

3. Meningkatkan mutu pendidikan dan pelayanan keperawatan berbasiskeperawatan holistik dalam meningkatkan derajat kesehatan masyarakat.

4. Mengembangkan karier dan prestasi kerja Ners - perawat Herbal sehingga dapat meningkatkan kesejahteraan Ners - perawat holistik di Indonesia.

5. Meningkatkan harkat, martabat dan kehormatan diri dan profesi keperawatan $\mathrm{f}$. Memfasilitasi dan melindungi anggota dalam menggunakan hak politik dan hukum.

6. Meningkatkan derajat kesehatan rakyat Indonesia menuju masyarkat sehat dan sejahtera.

7. Meningkatkan hubungan kerjasama dengan himpunan, lembaga dan institusi lain baik di dalam negeri maupun di luar negeri.

Perawat holistik adalah seseorang yang menempuh pendidikan formal keperawatan dan dinyatakan lulus oleh Program Pendidikan yang sah dan menjadi anggota PPNI yang berkompeten dalam keperawatan alternatif dan atau komplementer berbentuk pelayanan biologis, psikologis, kognisi, social, kultural dan spiritual yang saling mempengaruhi baik sehat dan sakit yang mencakup seluruh siklus kehidupan manusia. 5 nilai inti keperawatan holistik sebagai berikut: (Purnell \& Lange, 2011) 
1. Nilai inti 1: filosofi, teori, dan etika holistik;

2. Nilai inti 2: proses perawatan holistik;

3. Nilai inti 3: komunikasi holistik, lingkungan terapeutik, dan keragaman budaya;

4. Nilai inti 4: pendidikan dan penelitian holistik;

5. Nilai inti 5: perawatan diri perawat holistik.

Perawat holistik atau yang biasa disebut perawat komplementer, adalah perawat bersertifikat (Registered Nursel RN) yang menggunakan pendekatan pikiran-tubuh-jiwa-emosi dalam praktik keperawatan tradisional. Perawat holistik sering menggunakan bentuk pengobatan alternatif (dari timur) di samping pengobatan tradisional Barat dalam praktik mereka. Perawat yang mempraktikkan keperawatan holistik sering kali akan mendukung pasien untuk mampu mengintegrasikan kemampuan perawatan diri, kesadaran spiritual, dan refleksi diri ke dalam hidup mereka untuk membantu menjaga keseimbangan yang tepat antara pikiran, tubuh, dan jiwa mereka (RegisteredNurses.Org, 2021).

Meskipun tidak diwajibkan, beberapa perawat holistik mungkin perlu mendapatkan sertifikasi tambahan dalam teknik pengobatan terapeutik alternatif atau pelengkap lain yang membutuhkan keterampilan khusus, seperti akupuntur maupun hipnosis yang biasanya memerlukan program pelatihan terpisah dan memiliki persyaratan sertifikasi tersendiri (RegisteredNurses.Org, 2021).

Perawat holistik dan perawat umum memiliki banyak persamaan sekaligus perbedaan. Kedua jenis perawat tersebut secara formal dilatih dan dididik dalam standar etik dan praktik keperawatan. Keduanya dapat melakukan perawatan kepada pasien dan tugas-tugas lain dalam lingkup keperawatan seperti: Mengurus obat-obatan pasien, melakukan perawatan luka, menyusun rencana asuhan keperawatan, dan melakukan evaluasi terhadap asuhan yang diberikan kepada pasien.

Perawat holistik adalah perawat berlisensi yang menggunakan pengetahuan, teori, keahlian, dan intuisi keperawatan untuk mengenali dan merawat manusia secara keseluruhan dalam ruang lingkup, standar profesi dan spesialisasi keperawatan holistik. Perawat holistik memelihara keutuhan bio-psiko-sosio-kultural-spiritual yang ada pada diri pasien dengan menghargai kekuatan dan tantangan fisik, mental, emosional, spiritual dan lingkungan setiap 
orang dan menghormati nilai-nilai, keyakinan kesehatan, dan pengalaman kesehatan setiap orang.

Masalah klasik yang selalu dihadapi oleh perawat holistik adalah apakah perawat holistik tingkat lanjut harus memiliki sertifikasi atau keahlian khusus dalam terapi modalitas dan komplementer tertentu. Hal yang perlu diperhatikan oleh institusi pendidikan keperawatan yang ada antara lain dengan membimbing siswa dalam praktik reflektif dan dalam mengembangkan keahlian mereka di salah satu dari 3 bidang fokus: praktik pikiran-tubuh (Mind-Body), praktik manipulasi tubuh dan pikiran, atau praktik penyembuhan energi.

Keragaman minat mahasiswa keperawatan dalam mempelajari ilmu holistik perlu diimbangi dengan ketersediaan fakultas yang ahli di 3 area tersebut. Fakultas akan membimbing siswa dalam mengintegrasikan keterampilan ini ke dalam praktik keperawatan dan siswa diharapkan menjadi mahir atau ahli dalam 1 atau lebih modalitas pada saat mereka lulus (Purnell \& Lange, 2011). Mahasiswa yang diajar dari perspektif keperawatan holistik saat belajar di institusi akan mampu (a) memperoleh pengetahuan kritis tentang bagaimana cara merawat pasien secara holistik, (b) mempelajari pentingnya mengintegrasikan teori ke dalam praktik, dan (c) mengembangkan seperangkat keterampilan yang signifikan untuk digunakan selama praktik sebagai seorang perawat melalui pertimbangan pandangan individu sebagai sebuah kesatuan (Bice \& Bramlett, 2019).

Perawat holistik biasanya memiliki sertifikasi khusus dalam pemberian terapi holistik. Beberapa perawat holistik dapat memiliki lebih dari 1 sertifikat spesialisasi untuk suatu teknik komplementer tertentu (American Holistic Nurses Association, 2007). Mereka mampu memberikan asuhan keperawatan melalui pendekatan pikiran-tubuh-jiwa (mind-body concept) kepada pasien. Mereka mampu memandang pasien secara holistik dan memandang bahwa semua elemen di sekitar pasien berkontribusi pada kesehatan dan kesejahteraan pasien secara keseluruhan. Sebagai contoh: Pada kasus Ny. X yang mengalami dislokasi sendi, perawat pada umumnya memberikan kompres dan kolaborasi dengan medis untuk pemberian obat-obatan pereda nyeri. Berdasarkan kasus yang sama, seorang perawat holistik mampu mengintegrasikan pemberian terapi yang biasa diberikan secara umum dengan teknik komplementer seperti relaksasi napas dalam, musik terapi maupun aromaterapi 
(RegisteredNurses.Org, 2021). Beberapa teknik dan terapi umum yang digunakan oleh perawat holistik:

1. Teknik manajemen stres

2. Aromaterapi

3. Integrasi produk alami atau homeopati

4. Pijat

5. Hipnoterapi

6. Praktik penyembuhan Tiongkok dan Timur (Traditional Chinese Medicine / TCM)

7. Pembinaan kesehatan

Perawat holistik mampu mengintegrasikan fokus dan spesialisasi holistik yang dimilikinya dalam pekerjaan mereka serta mampu mempraktekkan apa yang dipelajari baik kepada pasien maupun kepada dirinya sendiri, hal ini dikarenakan mereka paham bahwa ketika mereka gagal mengimplementasikan kemampuannya dalam kehidupan sehari-hari, maka hal tersebut dapat mempengaruhi kemampuan mereka dalam memberikan asuhan kepada pasiennya. Perawat holistik mampu membantu individu serta kelompok untuk mencapai potensi terbesar dalam proses penyembuhannya menggunakan terapi komplementer yang diberikan (American Holistic Nurses Association, 2007). Wilayah kerja perawat holistik dapat terlihat secara jelas dalam penggambaran diagram di bawah.

Diagram 1.4. Lokasi Kerja Perawat Holistik di Amerika Serikat (Thornton, 2019)

\section{Lokasi Bekerja Perawat} Holistik

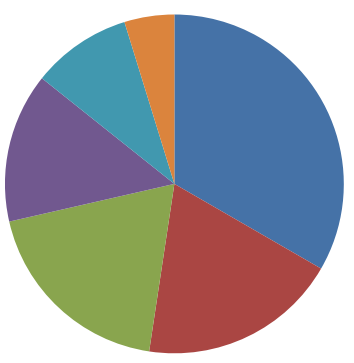

$$
\begin{aligned}
& \text { Rumah Sakit } \\
& \text { Perguruan Tinggi } \\
& \text { Praktek Mandiri } \\
& \text { Rawat Jalan } \\
& \text { Home Care } \\
& \text { Lainnya }
\end{aligned}
$$




\title{
Diagram 1.5. Terapi yang Dipergunakan Oleh Perawat Holistik di Amerika Serikat
}

(Thornton, 2019)

\section{Jenis Terapi}

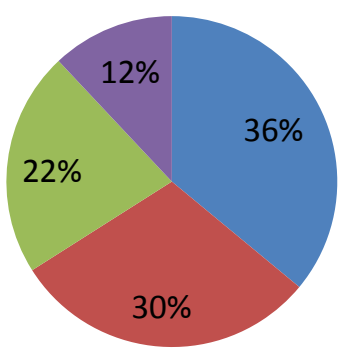

\author{
Intervensi pikiran- \\ tubuh \\ - Terapi Biofields \\ - Cognitive Behavioral \\ Therapies (CBT) \\ Metode Manipulasi \\ Tubuh
}

Thornton (2008) lebih lanjut menjelaskan dalam tulisannya tentang apa saja yang menjadi tugas dari perawat holistik dan perlu dipraktekkan dalam kehidupannya sehari-hari, meliputi:

1. Menjadi sosok perawat yang peduli dan mampu membawa efek terapeutik, Fokus utama dari perawatan holistik adalah membawa kembali "kepedulian" dan "penyembuhan" ke dalam sistem perawatan kesehatan pasien. Langkah pertama yang harus dilakukan perawat adalah dengan mencintai dan merawat diri sendiri, meskipun terlihat egois namun perilaku ini sangat penting bagi perawat. Ketika perawat mampu mencintai dan menerima kondisi dirinya sendiri, maka kemungkinannya untuk mampu memberikan kesembuhan melalui kehadirannya bagi pasien menjadi semakin tinggi.

2. Teladan untuk Hidup Sehat, Perawat holistik perlu untuk selalu berusaha menjadi model perilaku yang sehat dengan melakukan perilaku sehat yang optimal dalam setiap aspek kehidupan mereka (fisik, mental, emosional, sosial dan spiritual). Mencapai kesehatan yang optimal di semua bidang kehidupan kita adalah upaya seumur hidup yang harus terus menerus dipertahankan oleh seorang perawat holistik.

3. Komitmen pada Perawatan, Eksplorasi dan Kesadaran Diri, Perawat holistik harus selalu meluangkan waktu untuk mulai melihat ke dalam dirinya serta mengevaluasi kembali berbagai aspek kehidupannya. Beberapa praktik yang dapat dilakukan antara lain dengan meditasi, refleksi dan introspeksi diri, praktik kesadaran serta pembuatan jurnal harian.

4. Komitmen untuk Merawat Lingkungan, Seorang perawat holistik tentunya tidak dapat melepaskan kondisi lingkungan hidup di sekitarnya sebagai sebuah faktor pendukung kondisi sehat bagi individu. Perawat holistik perlu mempromosikan pentingnya 
lingkungan sehat serta mendorong individu dan keluarga untuk menjaga lingkungan sekitarnya. Seperti halnya Florence Nightingale yang menganjurkan dan memahami pentingnya kebersihan, udara segar, dan lingkungan yang bersih bagi pasiennya, begitu pula perawat holistik mempromosikan praktik yang membantu memastikan keberlanjutan bumi kita. Perawat holistik memahami bahwa kesehatan planet bumi memiliki keterkaitan erat dengan kesehatan setiap individu.

5. Pemusatan niat dan fokus individu terhadap kesembuhan, Pemusatan fokus dan penciptaan niat untuk penyembuhan adalah proses yang dilakukan perawat holistik sebelum interaksi pasien. Pemusatan fokus melibatkan pemusatan perhatian individu pada kondisi hati dan emosinya, mengesampingkan kekhawatiran dan pikiran negatif lain, serta meningkatkan fokus pada perasaan yang lebih positif seperti cinta dan kasih sayang.

6. Pengakuan atas Manusia sebagai makhluk spiritual, sakral dan memiliki sifat tidak terbatas dari sudut pandang energi, Perawat holistik harus mengakui bahwa manusia adalah makhluk yang memiliki kesakralan jiwa serta tingkat spiritual masing-masing. Orientasi ini membuat perbedaan dalam cara perawat melakukan pendekatan kepada satu pasien dengan pasien lainnya. Hal tersebut juga akan mampu mengubah cara kita berbicara, cara kita mendengarkan, cara kita berhubungan, dan cara kita berinteraksi dengan pasien.

7. Perawatan / Penyembuhan / Kehadiran yang menyembuhkan, karakteristik lain dari praktik holistik adalah kedalaman dan kualitas kehadiran yang mendalam yang dimiliki perawat dengan pasiennya. Jean Watson berbicara tentang "penggunaan diri sepenuhnya" dalam proses perawatan transpersonal yang dapat diartikan ketika perawat melakukan pendekatan dengan hati, maka dirinya akan mampu terhubung dengan pasien dan orang lain melalui pendekatan psikososial dan spiritual yang mendalam.

Peran perawat yang dapat dilakukan dari pengetahuan tentang terapi komplementer diantaranya sebagai konselor, pendidik kesehatan peneliti, pemberi pelayanan langsung, koordinator dan sebagai advokat.

\section{Peran Konselor}

Perawat dapat menjadi tempat bertanya, konsultasi, dan diskusi apabila klien membutuhkan informasi ataupun sebelum mengambil keputusan.

\section{Peran pendidik kesehatan}


Perawat dapat menjadi pendidik bagi perawat di sekolah tinggi keperawatan seperti yang berkembang di Australia dengan lebih dahulu mengembangkan kurikulum.

\section{Peneliti}

Melakukan berbagai penelitian yang dikembangkan dari hasil hasil evidence-based practice.

\section{Peran Caregiver}

Praktik pelayanan kesehatan yang melakukan integrasi terapi komplementer perawat lebih banyak berinteraksi dengan klien sehingga peran koordinator dalam terapi komplementer juga sangat penting.

\section{Peran advokat}

Perawat berperan untuk memenuhi permintaan kebutuhan perawatan komplementer yang mungkin diberikan termasuk perawatan alternatif.

\section{Referensi}

American Holistic Nurses Association. (2007). What Is a Holistic Nurse? Retrieved January 29, 2021, from https://www.ahna.org/About-Us/What-is-Holistic-Nursing

American Holistic Nurses Association. (2016). Mission statement.

American Holistic Nurses Association. (2021). Nurses and Complementary Healing $\begin{array}{lllll}\text { Modalities. } & \text { Retrieved } & \text { January } & \text { 29, } & \text { from }\end{array}$ https://www.ahna.org/Home/Resources/Healing-Modalities

Bice, A. A., \& Bramlett, T. (2019). Teaching Nurses From a Holistic Comfort Perspective. Holistic Nursing $\quad$ Practice, $\quad 33(3), \quad 141-145$. https://doi.org/10.1097/HNP.0000000000000325

Clarke, T. C., Black, L. I., Stussman, B. J., Barnes, P. M., \& Nahin, R. L. (2015a). Trends in the Use of Complementary Health Approaches Among Adults: United States, 20022012. National Health Status Report2, 10(79), 1-16.

Clarke, T. C., Black, L. I., Stussman, B. J., Barnes, P. M., \& Nahin, R. L. (2015b). Trends in the Use of Complementary Health Approaches Among Adults: United States, 20022012. National Health Status Report, 79, 1-16. Retrieved from https://www.ncbi.nlm.nih.gov/pmc/articles/PMC4573565/

Gazza, E. A., \& Hunker, D. F. (2014). Facilitating student retention in online graduate nursing education programs: a review of the literature. Nurse Education Today., 34, 1125-1129. https://doi.org/10.1016/j.nedt.2014.01.010. 
Himpunan Perawat Holistik Indonesia. NASKAH AKADEMIK HIMPUNAN PERAWAT HOLISTIK INDONESIA （ HPHI ） (2015). Retrieved from file:///C:/Users/ASUS/Downloads/885359.pdf

Himpunan Perawat Holistik Indonesia. (2018). Tentang Himpunan Perawat Holistik Indonesia. Retrieved February 1, 2021, from https://hphi.or.id/

Ibrahim, K. (2011). APPLICATION OF THE HOLISTIC NURSING CONCEPT IN CRITICAL CARE SETTING. In The 18th International Symposium on Critical Care and Emergency Nursing (pp. 21-23). Denpasar: PKGDI.

Karoliussen, M. H., \& Hov, R. (2020). Nightingale' s Legacy: Old Holistic Insight Supported by New Science. Holistic Nursing Practice, 34(4), 234-243. https://doi.org/10.1097/HNP.0000000000000393

Kementrian Kesehatan Republik Indonesia. (2013). RISET KESEHATAN DASAR. Jakarta.

Lincoln, V., \& Johnson, M. (2009). Staff Nurse Perceptions of a Healing Environment. Holistic Nursing Practice, 23(2), 183-190.

Maddalena, V. (2009). Cultural Competence and Holistic Practice. Holistic Nursing Practice, $23(3), 153-157$.

Purnell, M. J., \& Lange, B. (2011). Creating a Graduate Holistic Nursing Program. Holistic Nursing Practice, 25(3), 140-146. https://doi.org/10.1097/HNP.0b013e3182157bf9

RegisteredNurses.Org. (2021). Holistic Nurse. Retrieved January 29, 2021, from https://www.registerednursing.org/specialty/holistic-nurse/\#: :text=Holistic Nursing refers to a,symptoms of their present condition.

Rosa, W. (2017). Assessing the Readiness of Nursing Sectors in Low- and Middle-Income Countries to Adopt Holistic Practice: Rwanda as Exemplar. Holistic Nursing Practice, 31(3), 183-192. https://doi.org/10.1097/HNP.0000000000000207

Thornton, L. (2008). Holistic Nursing: A Way of Being, a Way of Living, a Way of Practice! Holistic Nursing, 55(January), 32-37. Retrieved from https://pubmed.ncbi.nlm.nih.gov/18286996/

Thornton, L. (2019). A Brief History and Overview of Holistic Nursing. Integrative Medicine Journal, 18(4), 32-33. 